\title{
SOCIAL SEMIOTIC IN COVID-19 PUBLIC SERVICES ADVERTISEMENT
}

\author{
Km Tri Sutrisna Agustia \\ Universitas Dhyana Pura \\ trisutrisna@undhirabali.ac.id \\ Hesteria Friska Armynia Subratha \\ Universitas Pendidikan Ganesha \\ hesteria.friska@gmail.com
}

\begin{abstract}
The phenomenon of miss-interpretation and the mismatch of the desired meaning in an advertisement has a significant impact on the development of the Covid-19 case in Bali. The purpose of this research is to align the problem of conveying a meaning in advertisements for public servicess about Covid-19 which are often not understood by the public so that there is a misunderstanding between the wishes of the appellers and the understanding of the public's target. The research design used a qualitative design collected from research subjects in the form of public services advertisements about Covid-19 collected from websites and print media in the form of visual media. The objects in this study are in the form of words, phrases, sentences, images, and colors in these advertisements. The research stage begins with the collection of public services data about Covid19 , then a picture of the correct meaning of the advertisement for public services regarding Covid19 will be drawn up based on semiotics. The results achieved in this study were the addition of semiotic science variables in the design of public services advertisements regarding Covid-19 so as to provide an overview of the suitability between the application of semiotics and the practice of giving advice and servicess as outlined in advertisements. The exact match between the desires and the meaning to be conveyed can be well developed to avoid misunderstandings between the advocate and the target public.
\end{abstract}

Keywords: advertising; covid-19; public; semiotics; services

\section{INTRODUCTION}

Public services advertisements aim to provide information to the public, and influence people's attitudes towards the problems being advertised. Public services advertisements are the result of cultural construction related to the process of representation, creation and implementation in society. Public services advertisement is a type of advertisement issued by the government, authorized parties, commercial or non-commercial organizations or institutions to achieve a social or socioeconomic goal to remind the public's understanding of a social phenomenon that is happening (Rudianto, 2008). Public services advertisements are facilities for delivering information to invite or educate the public to bring up an understanding of behavior and changes in attitudes towards the problems being advertised. From this understanding, an attitude will emerge which is a form of response that arises in a person that comes from experience and observation. Public services advertisements aim to communicate a product, share information persuasively. Advertising seeks to persuade and persuade consumers to understand a certain product so that it changes consumer behavior towards that product. Public services advertisements act as a constant reminder and affirm consumers so that they are always sure of the data or products advertised (Nisa, 2015)

Services ads on social media are made as attractive as possible in the form of videos, sounds, photos, writings and others. This is also related to the Covid-19 phenomenon which has been going on for more than 1 year in Indonesia with a fluctuating rate of decline and increase in cases. Covid-19 news is broadcast on various media such as periodic media (newspapers, 
magazines, tabloids), conventional communication media (whatsapp, line, etc.), electronic media (TV and radio) and social media (websites, social interaction applications such as Instagram, twitter, facebook). Information on social media is packaged creatively to attract consumer attention in the form of advertisements. Specifically, the public services advertisement regarding Covid-19 aims to provide understanding to the community about the Covid-19 phenomenon.

This situation has made the Indonesian government move in an effort to disseminate information and servicess related to COVID19. Patients' progress in recovery is reported to have surpassed 1.5 million people on May 2, 2021 , or the exact number increased to $1,530,718$ people with the percentage of $91.3 \%$. This cumulative recovery rate has been increased by the addition of 3,740 patients recovering each day. For the number of active cases or patients who still need medical assistance, currently there are 510 cases and a total of 100,760 cases with a percentage of $6.0 \%$. With the accumulation of the number of confirmed positive patients registered since the first case, it reached 1,677,274 cases (Kompas, 2021). Based on this data, the role of the community in reducing the Covid-19 case curve must be increased. One of them is through providing an understanding of Covid-19 itself. Understanding how to implement the Health and $5 \mathrm{M}$ protocols (wearing masks, washing hands with soap and running water, maintaining distance, staying away from crowds and limiting mobilization and interaction). Public understanding and awareness about the prevention of Covid-19 is still lacking. Meanwhile, the public attitude in implementing health protocols still seems low because residents still leave the house for recreational purposes, sit in groups, gather without wearing masks or keep a distance so that the possibility of transmission remains high (Chaolin, 2020). Promotional action to increase public understanding is urgently needed in order to increase their knowledge of health protocols in accordance with standard operating procedures. Based on this phenomenon, this study aims to highlight the role of citizen services advertisements in increasing public understanding of Covid-19.
This study intends to discuss the meaning of advertising that comes from the signifier or marker as well as the signified or marker that represents a meaning in the advertisement. If a meaning is communicated through the characteristics of the sender to the receiver, that meaning can be considered as a message. Advertising in the context of semiotics can be observed as an attempt to deliver messages by using a set of features in a system (Saussure, 1996). In social semiotics, advertising can be observed and created based on the bond between the signifier and the signified and it is a unity that cannot be separated. This can be practiced in advertising design in the form of selecting the right marker or symbol to represent the wishes of the advertisers themselves. In every object that is used by someone to reveal something to others, it always has a dual role as signifying something and at the same time as being signified. The effectiveness of the purpose of an advertisement is characterized by an understanding of the content of the advertisement itself (Barthes, 2008). This can be done to measure whether the advertisement has fulfilled its purpose. If an advertisement has not been found maximally, it can be modified (change or addition) to the advertising elements based on social semiotic principles. Modifications to existing advertisements were also made to maximize the effectiveness of advertisements in providing information and influencing people's attitudes. In the study, the following questions were discussed: a) What do the symbols on the services ads mean? b) What is the role of semiotics in the promotion of services ads regarding to increasing public understanding about Covid-19?

\section{METHOD}

The research design used was a qualitative research design. Qualitative itself uses multiple methods in terms of research focus, which involves an interpretation process on natural subject conditions (Ruslan, 2006). This approach was applied to obtain the maximum data from research subjects in the form of online questionnaires to a number of respondents regarding their responses to public appeal advertisements regarding Covid-19 and comparative advertisements modified by researchers using social semiotics principles 
and studies. The objects in this study are words, phrases, sentences, images and colors in public appeals about Covid-19. Data analysis in this study was carried out by organizing data, describing it into units, synthesizing it, arranging it into patterns, choosing which one is important, and making conclusions, so that it can be shared with others. The data processing procedure in this study begins with the processing of advertising documentation and the results of online questionnaires regarding advertisements used as research material (Denzin \& \& Lincoln, 2009). The results of the advertisement documentation will be analyzed using the Semiotic Theory to describe the meaning obtained in each advertisement. The results of the initial analysis will be used as the basis for online questionnaires that are distributed in 2 phases. The results of the documented interviews and online questionnaires were combined with other notes. Codification is done to facilitate data analysis on keywords from one data to another. In the data analysis technique, the process is carried out simultaneously through the data collection process. The process of data analysis uses thematic data analysis, thematic analysis is a way of identifying patterned themes in an event.

The symbol is a unity of 2 inseparable fields. Where there is a symbol, it will be followed by a system of meaning. This can be understood as a meaning which has two aspects that are captured by the human senses as a signifier, and the concept that is interpreted and understood is signified. He further said that the signifier lies at the level of expression and has a form or physical part such as sounds, letters, words, pictures, colors, objects and so on. The signifier lies at the content level of what is expressed through the expression level (Eco, 1979). The relationship between these two elements gives birth to meaning. A symbol will always refer to something else (object) which is called a reference. The red light refers to the path to stopping, the bright face refers to happiness, the tears refer to sadness. When the connection between the sign and the one referred to occurs, then in the mind of the person who sees or hears an understanding will emerge. The concept of signifier and signified according to Saussure is a meaning-forming component that cannot be separated from one another. Signifiers, are all meanings that are captured by our minds such as sound images, visual images, and so on. Meanwhile, signified, is the meaning or impression that is in our minds about what is caught. If viewed from the linguistic point of view which is the basis of the semiotic concept of Saussure, the parable can be analogous to the word and the noun door. The door in the signifier is a component of an object in the form of a box and is often made of wood, while the signified can be understood as something that connects one room to another. The combination of the signifier and signified then forms a sign on the door, not just an inanimate object used by humans. The concept of social semiotics can be implemented in the process of building, strengthening and clarifying the meaning of the information to be conveyed. The effectiveness of information in advertisements can be assessed from the product, logo and tagline (Sudjiman \& dan Zoest, 1992). The success of applying semiotics also depends on the cultural background of the target audience. One of the strategies that can be used to provide a clear picture of the conditions of the cultural environment regarding the needs and lives of consumers is through the relationship between culture, brands and consumers (Sudaryanto, 1993). This understanding is used in the process of building the concept and image of information in the public mindset.

\section{DISCUSSION}

These three parts represent a combination of Signified and Signifier. These parts are the ad segmentation of the entire public services advertisement.

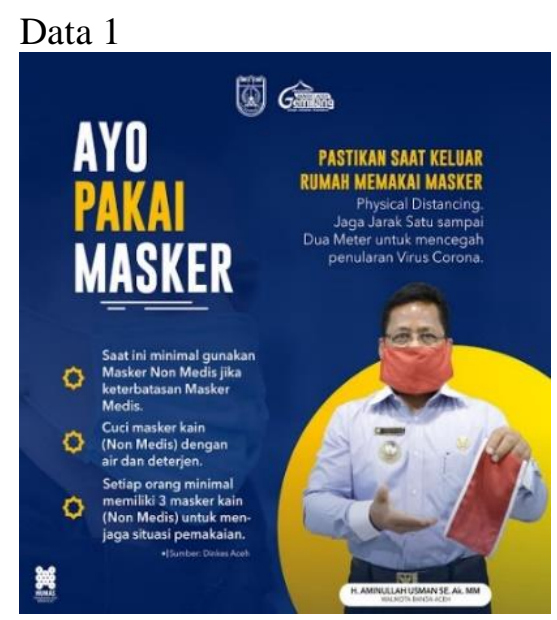


Table 1. Visual and Verbal

\begin{tabular}{|c|c|c|}
\hline & Signifier & Signified \\
\hline \multirow[t]{3}{*}{$\begin{array}{l}\text { Verbal: } \\
\text { Text }\end{array}$} & & $\begin{array}{l}\text { The main tagline to show } \\
\text { an encouragement to the } \\
\text { public regarding to the } \\
\text { main purpose of the } \\
\text { advertisement. The main } \\
\text { purpose of the } \\
\text { advertisement is always } \\
\text { wearing mask wherever the } \\
\text { people go. }\end{array}$ \\
\hline & $\begin{array}{l}\text { UaAR } \\
\text { KKER } \\
\text { cing. } \\
\text { mosth } \\
\text { gond. }\end{array}$ & $\begin{array}{l}\text { A reminder for the public } \\
\text { that beside wearing mask } \\
\text { when go out or activities } \\
\text { outside, it also should } \\
\text { follow some additional } \\
\text { effort to prevent Covid-19. } \\
\text { Beside wearing a mask, } \\
\text { public also should keep } \\
\text { physical distancing } 1-2 \\
\text { meter. }\end{array}$ \\
\hline & 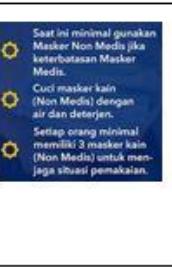 & $\begin{array}{l}\text { A term and condition when } \\
\text { wearing a mask for the } \\
\text { public. Kind of the mask, } \\
\text { how to clean the mask and } \\
\text { minimum amout of mask } \\
\text { that should owned by the } \\
\text { public. }\end{array}$ \\
\hline $\begin{array}{l}\text { Visual: } \\
\text { Picture }\end{array}$ & & $\begin{array}{l}\text { The Banda Aceh Mayor } \\
\text { picture. As a leader of the } \\
\text { city who become the role } \\
\text { model in how wearing a } \\
\text { mask as the exemplary } \\
\text { example for the public. }\end{array}$ \\
\hline
\end{tabular}

This ad shows a message that matches the main tagline AYO PAKAI MASKER. This tagline as a main message of the advertisement regarding a persuasive message for the public to wearing a mask as the one of the prevention act toward Covid-19. This main tagline also supported by 2 main message about additional prevention act toward Covid-19 as physical distancing and standard rule in how to wearing a mask. This services advertisement also supported by a figure of Banda Aceh Mayor who showing the right way in wearing a mask. This point has a purpose to share a message that even the leader of the region also follow the Covid-19 protocol and society that led by him should follow the protocol.
Data 2

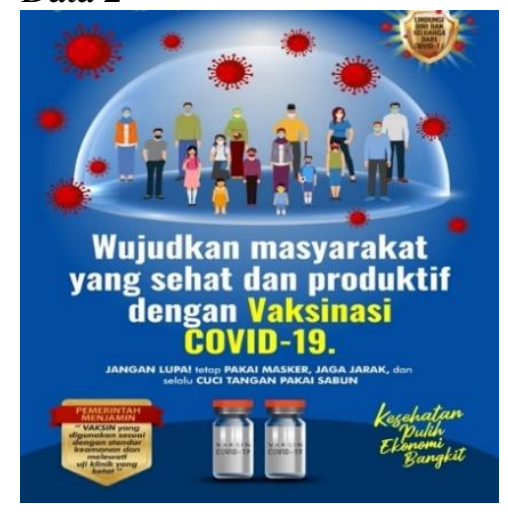

Table 2. Visual and Verbal

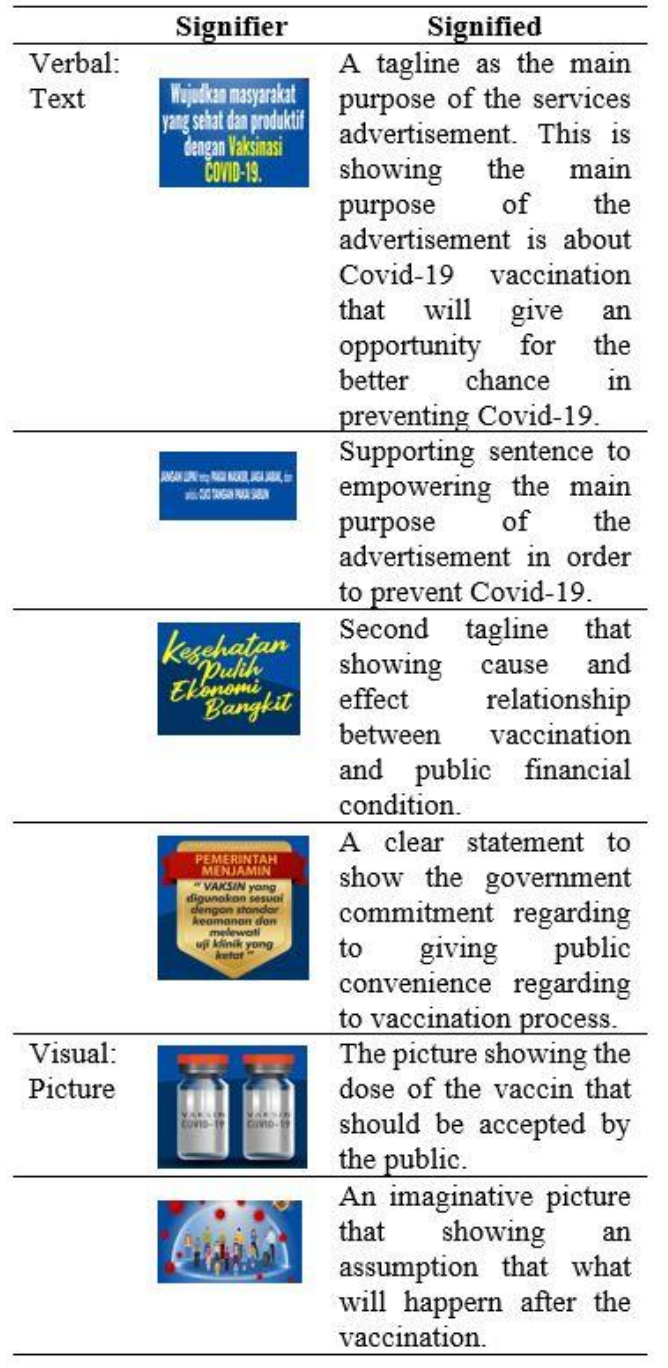

This advertisement shows information about the vaccination program. The government program that estimating will help to prevent Covid-19 pandemic. This advertisement pointing in what will happen or expected happen after the vaccination program. 
As the main tagline of Wujudkan masyarakat yang sehat dan produktif dengan Vaksinasi Covid-19 state that only from the vaccination program the preventation effort will has faster progress. From the vaccination expected that the herd community will happen and give a positive impact on public financial condition. The addition statement also showing even the public already got vaccinated, they should always implement Covid-19 protocol such as wearing mask, physical distancing and washing hands. The second tagline, also empowering the first tagline to strengthen the message that want to share in this advertisement that the vaccination program will support the financial condition improvement. The fourth statement that regarding to government guarantee regarding to the vaccination safety. Move to the visual aspect of the advertisement, there are two pictures belong to the dose and imaginative picture regarding to the herd community. In one vaccination program there will be given 2 doses each and from the imaginative picture of herd community that expected happem after vaccination program.

Data 3

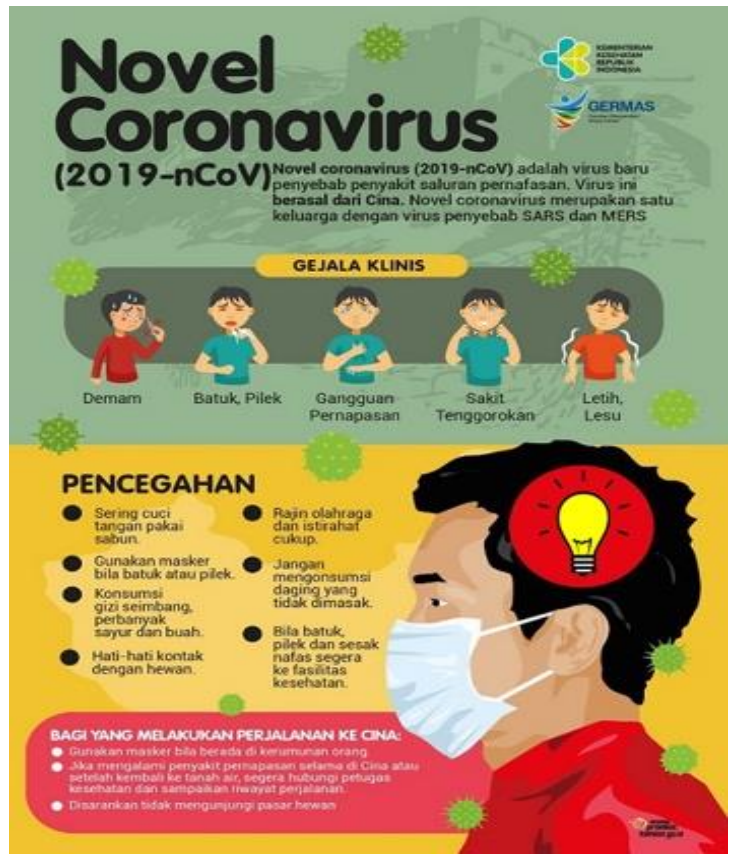

Table 3. Visual and Verbal

\begin{tabular}{lll}
\hline & \multicolumn{1}{c}{ Signifier } & \multicolumn{1}{c}{ Signified } \\
Text & $\begin{array}{l}\text { Novel opening of the } \\
\text { Coronavirus } \\
\text { advertisement } \\
\text { states the definition } \\
\text { and description } \\
\text { about the Covid-19. }\end{array}$ \\
\hline Visual: & $\begin{array}{l}\text { A grup of statement } \\
\text { about Covid-19 } \\
\text { prevention effort. } \\
\text { Steps of self } \\
\text { precaution } \\
\text { regarding to Covid- } \\
19 \text { prevention }\end{array}$ \\
\hline $\begin{array}{l}\text { Pn early warning } \\
\text { for any arrival or } \\
\text { departure to China. }\end{array}$
\end{tabular}

This part of the service advertisement shows the early Covid-19 pandemic appear in Indonesia. The service advertisement showing early precaution regarding to Covid-19. That's why this advertisement has a lot of general descriptin in order to understand by the public. This advertisement has 3 supporting statement to the description of Covid-19. Two verbal statement and 1 in visual matter. The verbal statements state an early precaution regarding to how to prevent Covid-19 and also pointing any arrival and departure from or to China. As we know, Covid-19 starting in China and that country has strict warning regarding any in or out travel. In this services advertisement also showing the general Covid-19 symptoms to make the public able to pre-act if has the same symptomps. And the last part of the advertisement showing optimism and positive thingking during pandemic. This part want to share about the power of positivity in worrying situation which sometimes helping for the immune system improvement.

The marking area is addressed by images in special purposes advertisement. The limited time advertisement above utilizes a recorded 
picture. These promotions can be the most alluring visual portrayal. Indexical pictures are immediate associations of two related articles or ideas. There are a wide range of approaches to utilize a semiotic way to deal with publicizing, each with its own objectives as far as narrating just as associating with the public at different levels. From the use of more straightforward and cleaner photography to the use of questionable and provocative pictures (and typically immaterial substance), these classes are used autonomously, comparably in facilitated exertion, to make something charming and ought to be seen as while thinking about everything. Message endeavoring to be passed on. The key is to consider the group, what they worth, and how to make a translation of those characteristics into huge visuals. In advancing and publicizing correspondences, semiotics expects an imperative part in choosing the accomplishment or frustration of any endeavor. Through the convincing utilization of verbal, visual and performative segments (exercises by buyers), associations can support their range to their customers. These delegate segments join logos, functions, social pictures, colors, remarkable individuals, text, sees, destinations, genuine environment, neighborliness and organizations, trademarks, and other touch centers. From the lodging ads, it tends to be seen that the utilization of images has met the accomplishment of helpful, exact and suitable publicizing with the end goal of the special commercial being made. From the description, showed that the advertisement especially in services advertisement which not have any profit orientation, any advertisement should has clear meaning and easy understandable by the public. This matter supported by social semiotic to strengthen the meaning of the verbal and visual aspect of the advertisement. Social semiotic played an important role in magnifying the meaning of any symbol applied in advertisement.

\section{CONCLUSION}

This research is an attempt to describe the way Indonesians use meaning symbolically. The material studied needs to be improved with the contribution of authority. If tags and markers are well synchronized, these aspects can provide a good overall understanding of the meaning and purpose of an advertisement. In this study, it was found that non-profit organizations have designed their advertisements in the best and most detailed way possible to give an unforgettable impression to the public. Public service announcements regarding Covid-19 have been designed in such a way to cover and help the public better understand this pandemic. Advertisers use verbal and visual forms with a simple discussion so that the meaning conveyed has a uniform and unambiguous understanding. This research also explains the role of social semiotics in non-profit advertising. How advertisers have compiled various images and verbally and visually to give a deep impression to the public.

In addition, the application of semiotics is very helpful in efforts to introduce Covid-19. Semiotics can be used as a study to determine the direction of non-profit advertising. As part of the branding indicated by a symbol in promotional advertising. The promotional ad above uses an index image. These ads have the ability to be the most attractive visual representation. This is also a support for increasing the government's outreach to the public regarding Covid-19 along with its health protocols and various ways of dealing with it. Through proper use of the verbal, visual and performative components, organizations can strengthen their outreach to society.

\section{REFERENCES}

Barthes, R. (2008). Elements of Semiology; Roland Barthes. Hill and Wang.

Chaolin Huang. (2020). Clinical features of patients infected with 2019 novel coronavirus in Wuhan, China. The Lancet 395 (10223), 65.

Denzin, \& \& Lincoln. (2009). Handbook of Qualitative Research. Pustaka Pelajar.

Eco, U. (1979). A Theory Of Semiotics. Indiana University Press.

Kompas. (2021). Kasus Covid-19 dalam Sehari. Kompas. https://www.kompas.com/tren/read/2021/ 06/25/122800965/20.574-kasus-covid19-dalam-sehari-ini-provinsi-denganpenambahan-tertinggi?page $=$ all

Nisa, K. (2015). Analisis Strategi Bisnis Ritel Islam Menghadapi Pesatnya Minimarket Waralaba (Studi Persaingan Usaha di Gribig Kudus). Sekolah Tinggi Agama 
Islam Kudus.

Rudianto. (2008). Pengantar Akuntansi. Erlangga.

Ruslan, R. (2006). Metode Penelitian Public Relations dan Komunikasi. Rajagrafindo Persada.

Saussure, F. de. (1996). Pengantar Linguistik Umum. Gadjah Mada University Press.
Sudaryanto. (1993). Metode dan Aneka Teknik Analisis Bahasa (Pengantar. Penelitian Wahana Kebudayaan Secara Linguistis). Duta Wacana.

Sudjiman, P., \& dan Zoest, A. van. (1992). Serba-Serbi Semiotika. Gramedia Pustaka Utama. 